PF 2020 (75/1): 355-372

https://doi.org/10.32798/pf.666

\title{
LILJANA MITKOVSKA
}

School of Foreign Languages

University AUE-FON, Skopje

e-mail: liljana55@yahoo.com

ORCID 0000-0002-4447-4289

ELENI BUŽAROVSKA

Faculty of Philology "Blaže Koneski"

University of Ss Cyril and Methodius, Skopje

e-mail: elenibuzarovska@t.mk

ORCID 0000-0002-1334-0501

\section{ZERO-MARKED VALENCY ALTERNATIONS IN MACEDONIAN}

\begin{abstract}
The paper discusses valency alternations without an overt marker in Macedonian. This seems to be an important typological feature that sets Macedonian apart from the other Slavic languages. The study provides a general description of the lability tendencies in Macedonian regarding its syntactic, semantic and distributional characteristics. About 150 verbs of this kind were detected and analysed. They fall into patient and agent preserving lability: verbs of the former type preserve the patient type participant, but in a different syntactic position (Toj sedna - Tie go sednaa'He sat - They seated him'), the latter keep the agent in subject position in both frames (Taa odi po poleto - Taa go odi poleto 'She goes across the field - She goes the field'). The verbs are classified according to syntactic and semantic criteria, with the aim of determining the most common event types that allow such valence alternations, as well as identifying some prevailing semantic correlations between the verb pairs.
\end{abstract}

KEYWORDS: argument structure, transitivization, lability, causativity, anticausativity

SŁOWA KLUCZOWE: struktura predykatowo-argumentowa, tranzytywizacja, labilność, kauzatywność, antykauzatywność 


\section{Introduction}

In this paper we analyse unmarked valency alternations in Macedonian verbs known as lability. In typological studies the term 'labile verbs' and 'lability' usually refers to valency alternations that are not morphologically marked in any special way (Kulikov, Lavidas 2014, p. 871), e.g.:

(1) a. Deteto najposle zaspa.

'The child finally fell asleep.'

b. Sevda go zaspa deteto.

'Sevda put the child to sleep.'

Typological studies have proved that languages differ systematically in expressing related causal and noncausal events (Haspelmath 1993; Nichols et al. 2004; Haspelmath et al. 2014). If the event is less likely to occur spontaneously, the transitive pattern is more basic and the intransitive one is derived as anticausative, whereas events that can be conceptualised as spontaneous tend to be coded as basic intransitives. Languages apply morphological or lexical strategies in coding related transitive and intransitive events. Nichols et al. (2004), in their analysis of a sample of 80 languages, define four such strategies. In the two oriented ones, one of the verbs is marked: (i) transitivising languages mark the transitive verb, (ii) detransitivising languages mark the intransitive verb. In the two nonoriented strategies, (iii) undetermined and (iv) neutral correspondences, none of the counterparts is more saliently marked. Labile or ambivalent verb pairs represent an undetermined, non-oriented strategy.

As a Slavic language, Macedonian applies a widespread detransitivising strategy marking the intransitive verbs related to causative events with a reflexive marker se. However, it has been noted that Macedonian shows a considerable tendency for use of basically intransitive verbs in transitive argument structure, unlike other Slavic languages. Конески $(1967 ; 1987)$ points out that in contemporary Macedonian the borderline between transitive and intransitive verbs is blurred, or rather totally rubbed out, as verbs such as umre 'die' or odi 'go', which express basically single-participant events, can be used transitively. This idea has been taken up and developed by several other authors (е.g., Спасов 1981, Корубин 1990, Јанушева, Спасов 2004), but it is still a puzzle in the Macedonian verb, and deserves a more systematic treatment.

The aim of our research is to investigate labile verb pairs in Macedonian in the light of some more recent typological findings (Dixon 1994; Nichols et al. 2004; Letuchiy 2009; Haspelmath et al. 2014, Kehayov, Vihman 2014; Zhang 2019, among others), and to present a systematic description of this phenomenon. In particular, the major goal of this study is to provide answers to the following questions: 
- What is the distribution of the labile verb types?

- For which semantic and syntactic classes of verbs is the labile pattern particularly common?

- Which semantic correlations between the corresponding verbs are prevailing?

For the purpose of this research we collected over 150 verbs that have attested lability tendencies. It has to be pointed out that this is not an exhaustive number - there are certainly other verbs, but we hope to have detected the ones that are well established in contemporary use (though they certainly display some dialectal and stylistic differences). The database was compiled in over a year by gathering examples of verbs used in different argument frames in dictionaries, literary and journalistic texts, as well as internet blogs, forums and other postings ${ }^{1}$. The verbs are classified according to several syntactic and semantic criteria that serve as a base for quantitative and qualitative analysis. We expect to find predominantly verbs with valency increasing strategy, since valency decreasing is regularly marked by the reflexive se. Both types of lability (A- and P-lability) will be documented, yet P-lability is expected to prevail, as has been shown crosslinguistically.

The paper is organised as follows: after a brief introduction we provide a theoretical framework underlying the analysis of lability. The central section presents the analysis of a number of labile verbs in standard Macedonian, based on their classification, and discusses the relations between corresponding valency alternations. The concluding section summarises the results of the investigation.

\section{Theoretical Background}

Broadly speaking, labile verbs are characterised as lexical items that are used in two (or more) different syntactic patterns, reflecting valency change in their argument structure with no particular overt morphological marking. In its narrow sense, most often adopted, the term 'lability' refers to verbs and verb forms that can be used in both transitive and intransitive syntactic patterns, such as the English verb break (They broke the window. The window broke.). For instance, Kehayov and Vihman (2014, p. 1061) give the following definition: "The notion of lability concerns the phenomenon of a single verb participating in both transitive and intransitive argument structure without any change in its formal marking." In certain approaches however, this general definition is made more precise. In his typological study on many diverse languages, Letuchiy (2009, p. 226) points out two parameters as necessary for the definition of labile verbs:

The examples in the text come from the Digital Macedonian Dictionary (http://h2344666. stratoserver.net/), the corpus of literary texts available at this site and other internet postings. Some examples were provided by the authors. 
(i) labile verbs have at least two distinct uses, one transitive and one intransitive;

(ii) the syntactically privileged argument (subject) in these different uses has different semantic roles.

Since both features do not necessarily combine in each case, it is agreed that labile patterns may involve two alternates, transitive or intransitive, though with different semantic roles of the subject. Kehayov and Vihman (2014, p. 1063-1064) refine the second parameter and add two more to make sure that the events coded by the labile pair are not identical, yet at the same time not too different from one another. Thus, semantic derivation through metaphor is excluded.

The distinction between the two basic types of lability, P-lability (patientpreserving lability) and A-lability (agent-preserving lability), identified by Dixon (1994) is still applied by linguists, though it has been revised to some extent. P-lability refers to correlated pairs of valency patterns with the same verb, in which the patientive participant is used in both, however in a different syntactic position: as a direct object in the transitive clause and as a subject in the intransitive one, as in the example with break. This type of syntactic alternation applies to causative - noncausative (inchoative) semantic alternation strategies, which have long been the focus of interest in typological research (e.g. Haspelmath 1993; Dixon 1994; Nichols et al. 2004; Haspelmath et al. 2014). They reflect the universal cognitive ability for construing complex events in different ways (Croft 1994). This is by far the most widespread pattern across languages, but other types of semantic correlation have also been observed within P-lability (Zhang 2019).

In the corresponding valency patterns of A-lability, the agent in the intransitive use is preserved in the transitive pattern, which is often illustrated with the verbs eat and drink (John drinks tea/ John drinks). However, as Letuchiy (2009, p. 226-227) notes, these examples reflect only syntactic lability, while semantically the verb remains bivalent in both uses, the second argument being obligatorily implied in the basic frame of the verb. That is why he considers such cases 'quasilabile'. Kehayov and Vihman (2014) modify the definition of A-lability, arguing that not all agent-preserving cases are quasi-labile. "The seemingly intransitive use of the verb drink differs substantially from the intransitive use of the verb walk in the pair John walked the dog vs. John walked: the activity of drinking contains an implicit object even when used intransitively, while the activity of walking does not imply any object." (Kehayov and Vihman 2014, p. 1064). We agree that not all A-labile alternations should be treated as quasi-labile, though it is often not easy to determine if the second argument is part of the basic semantic frame of the situation or not. It seems that there are degrees of inclusiveness, rather than a strict dichotomy. 
Kulikov and Lavidas (2014, p. 1145) point out that the broad definition of lability could also allow for the inclusion of other syntactic alternations, "such as locative alternation (cf. John sprayed paint on the wall vs. John sprayed the wall with paint) or dative shift (Mary gave John an apple vs. Mary gave an apple to John)". However, they are often considered different from typical cases of P-lability and A-lability. Kehayov and Vihman (2014, p. 1064) exclude them from their analysis, too, having explained that they violate most of the conditions they give for the domain of lability. In our analysis, we follow them in this respect.

Talking about different syntactic patterns of verbs, we refer to the linguistic concepts of valency, argument structure and transitivity. The definitions of these notions vary across linguistic frameworks. The term valency basically refers to the number and type of participants evoked by a predicate (usually, but not necessarily, a verb). It is also used to refer to the number and thematic roles of the dependent arguments that a verb takes, and in that sense it is analogous to the concept of argument structure ${ }^{2}$. Levin (2018) gives the following definition: "An argument structure typically indicates the number of arguments a lexical item takes (e.g., the core participants in the eventuality a verb denotes), their syntactic expression, and their semantic relation to this lexical item."

In typological studies the term valency refers to the number of core arguments, and it is included in the discussion on verbal categories marking changes in the syntactic pattern in which the verb is used, i.e. valency increasing and valency decreasing strategies (e.g. Dixon, Aikhenvald 2000). In cognitive construction grammar (e.g. Goldberg 1995; Hilpert 2014; Perek 2015), the terms valency and argument structure both refer to the relationship between the predicate and its participants (arguments), and they are used in syntactic as well as in semantic sense. Constructionists consider argument structure patterns as separate constructions ${ }^{3}$, associated with schematic meaning that reflects recurrent basic human experience (Goldberg 1995, p. 6). Since "[v]erbs can typically occur with more than one argument structure, with systematic variations in meaning" (Perek 2015 , p. 3), it is assumed that they can enter different constructions. They also distinguish between valency-increasing and valency-decreasing constructions.

In its syntactic aspect, transitivity refers to the property of coding the undergoing participant as a direct object of the verb. The well-known fact is that " $[t]$ here are two main transitivity types - intransitive (with core argument $S$ ) and transitive (with A and O) - and plain and extended subtypes of each (depending

2 Hilpert (2014, p. 26) claims that "[ $\mathrm{t}]$ he phenomenon that is described by the term argument structure is often also referred to as valency."

3 Constructions are considered basic language units, pairing a particular form with the meaning. Their meaning cannot be deduced from the meaning of its constituents, thus their meaning is non-compositional (cf. Goldberg 1995; Hilpert 2014; Perek 2015). 
on whether or not E is also in the core)."4 (Dixon and Aikhenvald 2000, p. 3). However, since the discourse-functional studies in the 1980s (especially in Hopper and Thompson's work) it has been accepted that there is no clear-cut borderline between the two types, and that transitivity is a matter of degree, contingent upon a number of factors, "which manifest themselves in a range of 'transitivity alternations', pertaining to a change of case and valency" (Kulikov et al. 2006, p. vii). In accordance with this view, cognitive linguistics considers transitivity a conceptual phenomenon related to the degree of asymmetric interaction between the participants, in relation to the prototypical action-chain model (e.g. Langacker 2008, p. 387-388). However, it is also a matter of interpretation, which elements of the verb frame are profiled and how their relation is presented. The same event may be coded as more or less interactive, which would affect the argument structure of the clause, or, from constructivists' point of view, the type of argument structure applied in a particular construction.

\section{Analysis of the subtypes of labile verbs in Macedonian}

Having outlined the theoretical concepts and principles this research is based on, we can now present the results of the database analysis. What is addressed first are overall descriptive quantitative facts; then we proceed to a more detailed qualitative analysis of each lability subtype (A-lability and P-lability) separately. As explained in the introduction, our sample is based on rather randomly collected examples and it is far from complete. However, we hope that it provides a solid basis for investigating the main tendencies in labile valency change strategies in the Macedonian verb system. The overall results presented in Table 1 support our expectations that P-lability should prevail, as the number of P-labile verbs is almost twice as high as the number of A-labile verbs. The number of P-labile verbs in standard Macedonian is considerably higher than in other Slavic languages (e.g. in Russian, Letuchiy 2015).

\begin{tabular}{|c|c|c|c|c|c|c|}
\hline $\begin{array}{l}\text { Syntactic pattern } \rightarrow \\
\quad \text { Type of lability } \downarrow\end{array}$ & Intr/Tr & $\mathrm{Tr} / \mathrm{Intr}$ & Intr/Intr & $\operatorname{Tr} / \operatorname{Tr}$ & \multicolumn{2}{|c|}{ Total } \\
\hline P-lability & 85 & 6 & 8 & 1 & 100 & $64 \%$ \\
\hline A-lability & 50 & 5 & 0 & 1 & 56 & $36 \%$ \\
\hline Total & $13587 \%$ & $117 \%$ & $8 \quad 5 \%$ & $2 \quad 1 \%$ & 156 & $100 \%$ \\
\hline
\end{tabular}

Table 1. Overall results

4 A and $\mathrm{O}$ stand for subject and direct object of transitive clauses, $\mathrm{S}$ for subject in intransitive clauses, and E for extended core argument in ditransitive clauses (Dixon, Aikhenvald 2000, p. 3). 
The table also shows the distribution of syntactic patterns in initial and secondary uses of the verbs featuring valency variation without overt marking. The syntactic pattern Intr/Tr is far more frequent, as expected. It means that the lability strategy in Macedonian is characteristic for the tendency of originally intransitive verbs to be used in transitive argument patterns. These relations have been determined on the basis of our intuitions, as well as the commonness and frequency of occurrence of the corresponding pairs. Certainly, impressionistic observations of this kind need to be supported by historical and statistical frequency research. Nevertheless, they are on a par with the findings in typological scholarship. What has been explained by principles of iconicity (cf. Haspelmath 1993; Givón 1991, p. 106) and form-frequency correlation (Haspelmath et al. 2014 ) is that core events of causative-noncausative verb pairs tend to be conceptually and formally less marked, if only they are more likely to occur spontaneously (freeze, melt). Contrary to that, in the pairs expressing the events that are less likely to occur spontaneously, the core event is perceived as secondary and often marked with the anticausative marker. In the former, the transitive member is usually secondary and often marked with a causative marker ${ }^{5}$.

Our intuition is also supported by the fact that other linguists discussing labile verbs in Macedonian grammars have equally expressed the opinion that the lability phenomenon in this language principally covers the ability of primarily intransitive verbs to be used transitively. Конески (1987, p. 354) states that "there are situations when a direct object can be used with primarily intransitive verbs, turning them into transitive verbs". He also refers to "transitivization of intransitive verbs" and "secondary transitive constructions", giving verb examples similar to those in our sample. Корубин (1990, p. 321) names such processes 'argumentation of intransitive verbs', in the process of which they acquire causative features.

As explained above, the difference between P- and A-lability rests upon the correlation between participants, as well as on how they are coded in the corresponding argument structure pattern of the verb. In P-lability, the subject of the intransitive clause correlates with the direct object in the transitive pattern, while the subject slot is occupied by a newly included participant, presented as an agent or a causer. This means that the event expressed in a sentence is enriched by a component of causation. In A-lability alternations the initiating participant is preserved in the derived pair, and an argument is added in the target domain. This is very often a participant that is implicitly present in the verb frame: it is profiled in the derived situation, which results in its slight semantic modification. In our analysis below, we show that these two processes differ in the semantic

Haspelmath (1993, p. 107) maintains that languages may differ slightly in the way situations are conceptualized in the verb, which results in different directions of derivation in inchoative/causative alternations. 
types of verbs which undergo valency alternation, and which are paired with different types of semantic correlation between the alternate valency patterns.

\section{Properties of P-lability valency alternations}

Within P-lability we found three types of correlation between the alternating valence patterns of a verb. As shown in Table 2, the causative pattern dominates, as it is expected for such type of relation between the situations described.

\begin{tabular}{|c|c|c|c|c|c|c|c|c|}
\hline $\begin{array}{c}\text { SEMANTIC } \\
\text { TYPES } \rightarrow \\
\text { CORRELA- } \\
\text { TIONS } \downarrow\end{array}$ & $\begin{array}{l}\text { change } \\
\text { of state }\end{array}$ & $\begin{array}{l}\text { change } \\
\text { of } \\
\text { position }\end{array}$ & $\begin{array}{l}\text { sponta- } \\
\text { neous } \\
\text { process }\end{array}$ & activity & $\begin{array}{l}\text { phase } \\
\text { verb }\end{array}$ & $\begin{array}{l}\text { sensory } \\
\text { stimulus }\end{array}$ & & otal \\
\hline causative & 53 & 7 & 8 & 6 & 7 & 4 & 85 & $85 \%$ \\
\hline anticausative & 0 & 4 & 0 & 3 & 0 & 0 & 7 & $7 \%$ \\
\hline metonymy & 0 & 0 & 3 & 1 & 0 & 4 & 8 & $8 \%$ \\
\hline Total & 53 & 11 & 11 & 10 & 7 & 8 & 100 & $100 \%$ \\
\hline
\end{tabular}

Table 2. Semantic types of verbs and types of correlations between the corresponding verbs in P-lability alternations

Crosslinguistically, causativisation is a major valence increasing strategy (e.g. Dixon, Aikhenvald 2000) and it is often formally marked. With $87 \%$ of all P-labile verbs in our sample, causation appears as the major mechanism in this group. It is typically found with verbs expressing change of state (53 tokens). Change of state and position verbs express complex situations which lend themselves to different construals. They indicate that something was in a state or position and then it transferred to a different state or position. For instance, Toj ozdrave 'He got healthy' means that he was ill and now he is healthy. The verb may code just the final state as an autonomous/spontaneous event, or the changing phase, in which case a cause has to be profiled. According to Zhang (2019, p. 25): "This also sheds additional light on the factor of spontaneity. If a change of state is likely to occur spontaneously, the chance of the agent being profiled as the trajector will be low, and thus it is more likely to be expressed by an intransitive structure." Most of the change of state verbs in our sample are derived from adjectives (živne 'revive', zaglupi 'become stupid', izbledi 'go pale', ogoli 'bare', ozdravi 'heal'), and only some of them from nouns (razlista 'put out new leaves', rǵosa 'rust').

(2) a. Své́ata omekna vo rakata na baba Stana.

'The candle got soft in old Stana's hand'.

b. Majstorot gi omekna kožite.

'The craftsman softened the leather.' 
(3) a. Ako ostane na dožd, kofata ḱe 'rǵosa.

'If it stays in the rain, the bucket will rust.'

b. Vlagata go 'rgjosuva železoto.

'Moisture makes iron rust.'

Some verbs are prefixed perfective derivatives from the imperfective verbs. It is worth mentioning that some of the basic imperfective verbs cannot be used transitively at all, except for the secondary imperfectives in generic use: zaspie, ${ }^{\star}$ spie, zaspiva 'fall asleep'; zamolči, *molči, zamolčuva 'stop talking' (example 4). Other semantic types of verbs also display this kind of behaviour. It has been noted by Конески $(1987$, p. 359) that the development of transitivity is more characteristic of perfective verbs, even though transitivised imperfective verbs are also encountered.

(4) a. Site zamolčea.

'Everybody fell silent.'

b. So toa gi zamolče site.

'With this s/he silenced everybody'

Macedonian is one of the rare languages that use the verb umre 'die' transitively (5). Out of 21 languages in Haspelmath's typological study (1993, p. 104), only one language uses lability strategy for this type of events, while 16 languages use suppletion. However, though the transitive pair in Macedonian does mean 'cause to die', it cannot be used to express killing by a violent action, but only indirect causation.

(5) Loš doctor može da te umre.

A bad doctor can cause your death.'

Change of position verbs are of similar kind. All 8 examples are inchoative perfective verbs (e.g. sedne 'sit down', legne 'lie', potone 'sink', propadne 'fall through'). The primary imperfective counterparts are not used in the transitive pattern, as they do not contain the element of change and do not invoke a causative phase ( go sedna deteto; ${ }^{\star}$ go sedi deteto; go sednuva deteto 's/he seated the child').

Spontaneous process verbs express events which can be easily conceptualised as occurring spontaneously, but in this case the focus can be placed both on the on-going process (6) and on the resulting state (7). The former makes use of imperfective verbs (e.g. vrie 'boil', gori 'burn', raste 'grow'), and the latter of perfective ones (zovrie 'come to boil', izgori 'burn', porasne 'grow up'). One could classify perfective verbs as change of state, yet due to the similarity of the corresponding events the aspectual pairs are not separated:

(6) Kafeto vrie. Kafeto zovre.

'The coffee is boiling.' 'The coffee came to boiling.'

(7) Kafeto ne go vrieme. Vnimavaj da ne go zovrieš kafeto.

'We do not boil coffee.' 'Try not to boil the coffee.' 
Phase verbs exhibit similar properties, expressing both an on-going phase (beginning, end or continuation), or some reached phase of the event, so both imperfective and perfective verbs are used in the alternation:

(8) a. Deteto sega počnuva da zboruva.

'The child is starting to speak now.'

b. Deteto počna da zboruva rano.

'The child started to speak early.'

Verbs classified as activities are events that occupy the middle position of the inchoative/causative alternation cline proposed by Haspelmath (1993, p. 105). They mainly involve human participants (e.g. brza 'hurry', zadocni 'be late', zastane 'stop walking', proodi 'start walking' - referring to children, $u \check{c} i_{2}$ 'learn') ${ }^{6}$, which makes them less likely to be coded as autonomous events. This could be the reason why they exhibit atypical behaviour and some get the reflexive marker $s e$ in certain intransitive uses ( 9 and 10). This indicates an inclination to anticausative orientation, in which the transitive situation is perceived as more basic. The perfective member expresses a resultant state and the imperfective one an activity, but the latter is not equally common:

(9) a. Ḱe počekam jas, ne (se) brzam.

'I'll wait, I am not in a hurry.'

b. Užasno (se) brzam, nemam vreme.

'I'm in awful hurry, I have no time.'

(10) Tome (se) uči da vozi kola.

'Tome is learning to drive.'

Verbs denoting sound production or other types of sensory stimuli also form a less unified class (11). The intransitive pattern expresses a kind of sensory stimulus emitted by a source, while the transitive pattern involves a human experiencer exposed to the stimulus (e.g. mirisa 'smell') or an agent producing the stimulus by manipulating an object (bie 'hit', eksplodira 'explode', svetne 'shine'):

(11) a. Kambanata bie. 'The bell tolls.

b. Popot ja bie kambanata.

'The priest is tolling the bell.'

Anticausative labile alternations do not occur frequently in Macedonian. The anticausative and reflexive derivation with the reflexive marker se is quite regular and widespread in this language. However, we registered only 7 verbs (though there may be more of them) that enter this kind of labile valency alternations: 4 change of position

6 The numbers in subscript indicate different senses of the verb. 
(zaglavi 'get stuck', mrda 'move', svrti 'turn', dobliži/približi 'approach') and 3 activity verbs (navikne 'get used,' pukne ${ }_{2}$ 'burst', isturi ' ${ }_{1}$ pour'). The transitive member of the pair is conceptually basic as the events are less likely to occur spontaneously, and in some of their uses they are linked to human participants (as navikne 'get used'); on the other hand, the intransitive member has a secondary status, and it acquires anticausative meaning (or reflexive, in the case of human participants). Moreover, the intransitive member is alternatively used with the se marker. Compare the examples in (12):

(12) a. Puškata zaglavi meǵu dva kamena. 'The rifle got stuck between two stones.'

b. Zaglaviv vo zemja koja nema koronavirus. 'I got stuck in the country that has no corona virus.'

c. Deteto se zaglavi meǵu rešetkite od ogradata.

'The child got stuck inbetween the bars of the fence.'

The reasons for lability in these verb pairs and the relation between the grammatically marked and unmarked use of the intransitive verb need to be further investigated.

The correlation dubbed metonymy in our classification refers to some secondary changes in the verb use, motivated by metonymic extensions, the event being attributed to the container in which it occurs (13 and 14):

(13) Vodata vrie vo tendžereto. > Tendžereto vrie.

'The water is boiling in the pot. The pot is boiling.'

(14) Nešto tropa vo motorot. > Motorot tropa.

'Something rattles in the engine. The engine rattles.'

Such pairs do not present prototypical lability. We can, nevertheless, marginally include them in the labile class, since the type of event does not change and, even though the syntactic pattern remains intransitive, the role of the subject changes, which fulfills one of the conditions set by Letuchiy (2009, p. 226).

\section{Properties of A-lability valency alternations}

Following Letuchiy's (2009) classification criteria for types of lability, we excluded from our analysis A-labile verbs with implicit object ( eat, I drink). However, we decided to include a large group of verbs that undergo transitivisation, but preserve the same argument in subject position and thus can be considered as A-labile verbs. These pairs can be compared to the valency increasing strategies called applicative, as defined by Dixon and Aikhenvald (2000, p. 12). Table 3 shows the correlation types of relations between A-labile alternations and the distribution across semantic verb classes. It differs considerably from P-labile verbs. 


\begin{tabular}{|c|c|c|c|c|c|}
\hline \multirow{2}{*}{$\begin{array}{l}\text { Semantic types } \rightarrow \\
\quad \text { Correlations } \downarrow\end{array}$} & \multirow{2}{*}{$\begin{array}{c}\text { natural } \\
\text { phenomena }\end{array}$} & \multicolumn{2}{|c|}{ activities } & \multirow{2}{*}{\multicolumn{2}{|c|}{ Total }} \\
\hline & & physical & mental & & \\
\hline Applicative & 5 & 37 & 3 & 46 & $80 \%$ \\
\hline Quasi-lability & 0 & 4 & 2 & 6 & $10 \%$ \\
\hline Anticausative & 0 & 5 & 1 & 6 & $10 \%$ \\
\hline Total & 5 & 46 & 6 & 57 & $100 \%$ \\
\hline
\end{tabular}

Table 3. Semantic types of verbs and types of correlations between the corresponding verbs in A-lability alternations

The core A-labile verbs belong to a small semantic class of verbs of natural phenomena (15 and 16). The class consists of five monovalent verbs (duvne 'the wind blows', zajde 'the sun sets', navrne 'it rains', ogree 'the sun rises', osamne 'the day breaks') denoting natural phenomena. In the transitive pattern, these inherently intransitive verbs undergo valency increase: the second argument (typically, but not necessarily, personal) is introduced into the semantic frame of the verb as an affected participant:

(15) a. I taka osamna ubav den.

'And thus a beautiful day broke'

b. Ja minavme granicata i nè osamna negde kaj Salcburg.

'We crossed the border and the day broke on us somewhere near Salzburg.'

(16) a. Sonceto zajde zad šumata.

'The sun set behind the forest.'

b. Odev dodeka me zajde sonceto.

'I walked until the sun set on me.' (lit)

The subject is a natural force that acts on the affected patient, occupying the object position. The verb placed in the resultant transitive schema indicates a patientive relation between a given natural phenomenon and a person or inanimate entity exposed to the effects of this phenomenon. Since the transitive pattern highlights the result of the given force on the patient, the verb is usually in the perfective aspect, but imperfective use is not totally excluded. The reasons why these verbs demonstrate valency increase may be sought in language contact with demotic Greek, in which such verbs have transitive uses. In addition, the transitivisation strategy may have been applied in analogy with those reflexive verbs that refer to similar natural phenomena and have normal transitive counterparts (se stemni 'it got dark' - me stemni 'it got dark on me', se razdeni 'the day broke'- me razdeni 'the day broke on $\left.\mathrm{me}^{\prime}\right)^{7}$. Even though the two

7 The English translations are literal. 
elements of these pairs (intransitive/transitive) differ formally due to the presence of the intransivitising reflexive se in the intransitive pattern, the semantic relation between the two situations is comparable.

Verbs belonging to the second class of A-labile applicative verbs express situations which are low in transitivity, but involve a salient second participant. In the intransitive construal such a participant is coded as an adjunct, whose status changes to a thematic argument in the transitive construction ${ }^{8}$; however, the verb itself bears no explicit formal marking of transitivisation ${ }^{9}$. This alternation is very productive in Macedonian, and extends to verbs which crosslinguistically do not usually belong to labiles.

The "promotional" construal characterizes a class of around 40 verbs that typically express controlled physical and mental activities. They fall into several semantic subgroups: the majority of them are motion verbs that code the agent's movement in some location (gazi 'tread', stigne/dostigne 'reach', grebe 'scratch', lazi 'crawl', odi 'go', nadleta 'fly over,' stapne 'step', patuva 'travel', po/mine 'pass', premine 'pass through', prepliva 'swim across', preleta 'fly across', skoka 'jump', sleze 'go down', pretrči 'run through'). The relation between the agent and the location of the movement is signified by a corresponding preposition ( $p o, n a, n a d, p r e k u$ ), if expressed explicitly:

(17) a. Nik Valenda premina preku Golemiot kanjon na čelicno jaže.

'Nick Valenda crossed the Great Canyon on a steal rope.'

b. Ilegalec vo kombe ja premina granicata.

'An illegal migrant crossed the border in a van.'

In the intransitive pattern, the verb's locative argument occupies the syntactic position of an adjunct at the clause periphery. In the transitive pattern, the locative argument becomes part of the argument structure. Via applicative strategy it is promoted to the status of a core argument. Upon the promotion, it takes the direct object position and assumes the form of an NP. This results in the rise of holisticity implicature: the locative participant is presented as "subsumed" by the agent's activity.

The activity may be performed with what is expressed by a peripheral instrumental (vrti 'turn', mavta 'wave', pukne 'burst', sviri 'play music') or a sociative argument (igra 'play, komunicira 'communicate'). The instrumental relation characterizes two verbs of manipulation involving people (vladee 'govern', upravuva

8 Hale \& Keyser (1986) explain this kind of transitivity alternation in English as a syntactic advancement of an oblique complement to the object relation (The horse jumped the fence, the horse swam the river, John walked the trail).

9 The observation goes against the typological tendency, observed in Dixon and Aikhenvald (2000, p. 12), that " $\mathrm{t}]$ here is some explicit formal marking of an applicative construction, generally by an affix or some other morphological process applying to the verb". 
'rule'). The pattern with the promoted peripheral constituent in the object position foregrounds its denotate being affected by the agent's activity:

(18) a. Što znači koga kučeto mrda so opaškata levo?

'What does it mean when the dog wags with its tail to the left?'

b. Kučeto ja mrda opaškata bidejќi e sreḱno.

'The dog wags its tail because it is happy.'

We may hypothesise that these verbs of motion are more prone to labilisation because of the agentivity of the subject in the intransitive uses. The successful realisation of the transitive activity presupposes the agent's will and determination to perform it (compare English jump the wall vs. jump over the wall). This is strengthened by the fact that the applicative extension also occurs in the verbs that do not strictly encode locomotion but have agentive subjects. The agent's activity may be directed at another participant (duva 'blow', kapne 'drip'), and some verbs denote a production of sounds typical of a given activity (lae 'bark', plače 'cry', pukne 'snap', tropne 'knock'):

(19) a. A taa odvrzana ne lae na sekogo.

'She does not bark at everyone when unleashed.'

b. Vleguva vo dvorot, a od kukičkata izleguva kučeto i počnuva da go lae. 'He comes into the yard, and a dog gets out of its kennel and starts barking at him.'

It should be pointed out that the transitive pattern of the verbs gleda 'look', $u d r i$ 'beat' and mava 'hit' is more common than the intransitive pattern with a peripheral argument, if their actants are animate (20). This suggests that the derivation may have had the opposite direction: transitive > intransitive, which is motivated by the need to convey a distancing effect. We classified them as anticausative, i.e. the opposite of applicative, but these verbs exhibit complex behaviour sensitive to the semantics of the subject argument, so they require further investigation:

(20) a. Koga ne možeš po magareto udri po samarot.

'When you cannot hit the donkey, hit the saddle.'

b. Nekoj go udri sudijata so topkata.

'Somebody hit the referee with ball.'

The agentivity component is weakened when the applicative derivation operates on several verbs coding mental and emotional processes (misli 'think', žali and boleduva both meaning 'grieve'). However, their subject referents should be considered as willing agents rather than experiencers, since in a way they "choose" to go through a given mental or emotional process:

(21) a. Mi pomognaa prekrasni luǵe i ušte mislam na niv.

'Some wonderful people helped me, and I still think about them.' 
b. Celo vreme gi mislam, zatoa što imaat potreba od pogolema pomoš.

'I am thinking of them all the time because they are in need.'

We find two non-agentive verbs within this class: padne 'fail an exam' and kape 'drip'. The former is a metaphorical extension of a motion verb (padne 'fall'), and the latter may be a stylistic innovation in the colloquial use. Kape 'drip' means that drops of some liquid fall down on something, expressed by a locative argument; thus the verb involves an inanimate subject: tears/water/liquid dripping on some surface and affecting it:

(22) a. ...solzite í kapat na Stojanovo lice.

'Her teardrops are falling on Stoyan's face.'

b. Me interesira dali inspektorite gi kape voda od klimatizer.

'I would love to find out whether the inspectors got dripped from air-conditioner.'

The inclusion of several other verbs such as zabrza 'step up', mete 'sweep', igra 'play a game', sonuva 'dream', trča 'run', and uč $i_{1}$ 'learn' is questionable, because referents of their direct objects are evoked contextually in the intransitive use, and they are just made explicit in the transitive pattern. Therefore, they are treated as quasi-labile. However, some of them may choose different, unpredictable object referents (23):

(23) a. Toj zabrza, sakaše da ja premine ulicata ...

'He stepped up, he wanted to cross the street.'

b. Tie neusetno gi zabrzuvaa čekorite...

'They unintentionally speeded up their steps.'

c. Zapadot se obiduva da go zabrza rešenieto za ovoj problem.

'The West is trying to step up the solution to this problem.'

\section{Concluding remarks}

The research presented in this paper has shown that verb lability in standard Macedonian is represented by both P-and A-lability types, as defined by Dixon (1994, p. 6). P-labile verbs are considerably more numerous and belong to semantically more versatile classes. All such verbs express events causing some change in the undergoing participant, thus a transitive clause is in most cases high on the transitivity scale. Consequently, what dominates here is the causative type of alternation, including some verb types that are not commonly recognised as labile in other Slavic languages. On the other hand, A-labile verbs represent cases of transitivisation, which result from the applicative extension of an argument structure, accompanying the promotion of some more or less salient oblique participant. This also seems to be a productive strategy, especially in colloquial language. 
The presence of a higher number of labile verbs in Macedonian as compared with other Slavic languages may be explained by both externally and internally motivated language processes: language contact with neighbouring languages (pointed out by Конески 1987 and especially by Тополињска 1995, p. 172), and the effect of the economy principle driving language change. These observations need further investigation.

\section{Bibliography}

Croft, W. (1994). Voice: Beyond control and affectedness. In: B. A. Fox, P. Hopper (eds.), Voice: Form and function (89-118). Amsterdam: John Benjamins.

Dixon, R.M.W. (1994). Ergativity. Cambridge: Cambridge University Press.

Dixon, R., Aikhenvald, A. (2000). Introduction. In: R. Dixon, A. Aikhenvald (eds). Changing Valency: Case Studies in Transitivity (1-29). Cambridge: Cambridge University Press.

Givón T. (1991). Isomorphism in the grammatical code: Cognitive and biological considerations, Studies in Language, 15, 85-114. DOI: https://doi.org/10.1075/sl.15.1.04giv

Goldberg, A.E. (1995). Constructions: A Construction Grammar Approach to Argument Structure. Chicago: University of Chicago Press.

Hale, K., Keyser, J. (1986). Some transitivity alternations in English. ASJU, XX(3), 605-638.

Haspelmath, M. (1993). More on the typology of inchoative/causative verb alternations. In: B. Comrie, M. Polinsky (eds.), Causatives and transitivity (87-120). Amsterdam: Benjamins.

Haspelmath, M. et al. (2014). Coding causal-noncausal verb alternations: A formfrequency correspondence explanation, Journal of Linguistics, 50(3), 587-625. DOI: $10.1017 /$ S0022226714000255

Hilpert, M. (2014). Construction Grammar and its Application to English. (Edinburgh Textbooks on the English Language). Edinburgh: Edinburgh University Press.

Januševa, V., Spasov, Lj. (2004). Za nekoi pointeresni slučai na proširuvanje na ednoargumentskite predikati vo makedonkiot jazik. In: Zbornik trudovi od 29 naučna konferencija SMJLK (237-253). Skopje: UKIM.

Kehayov, P., Vihman V. (2014). The lure of lability: A synchronic and diachronic investigation of the labile pattern in Estonian, Linguistics, 52(4), 1061-1105. DOI: 10.1515/ ling-2014-0016

Koneski, B. (1967). Istorija na makedonskiot jazik. Skopje: Kultura.

Koneski, B. (1987). Gramatika na makedonskiot literaturen jazik. Skopje: Kultura.

Korubin, B. (1990). Na makedonsko gramatički temi. Skopje: Institut za makedonski jazik „Krste Misirkov”, 317-322. 
Kulikov, L., Lavidas N. (2014). Introduction, Linguistics, 52(4), 871-877. DOI: 10.1515/ ling-2014-0010

Kulikov, L. et al. (eds.). (2006). Case, valency and transitivity. Amsterdam: John Benjamins.

Langacker, R.W. (2008). Cognitive grammar. A basic introduction. Oxford: Oxford University Press.

Letuchiy, A. (2009). Towards a typology of labile verbs: Lability vs. Derivation. In: P. Epps, A. Arkhipov (eds.), New Challenges in Typology: Transcending the Borders and Refining the Distinctions (247-268). Berlin: Mouton de Gruyter.

Letuchiy, A. (2015). Historical development of labile verbs in modern Russian, Linguistics 53(3), 611-647.

Levin, B. (2018). Argument Structure, Oxford Bibliographies obtained from https:// www.oxfordbibliographies.com/view/document/obo-9780199772810/obo9780199772810-0099.xml (DOI: 10.1093/OBO/9780199772810-0099)

Nichols, J. et al. (2004). Transitivizing and detransitivising languages, Linguistic Typology, 8(2), 149-211. DOI: 1430-0532/2004/008-0149

Perek, F. (2015). Argument Structure in Usage-Based Construction Grammar, Experimental and corpus-based perspectives. Amsterdam-Philadelphia: John Benjamins Publishing Company.

Spasov, Lj. (1981). Preodnosta na glagolite vo makedonskiot jazik. Doktorska disertacija. UKIM, Skopje.

Topolinjska, Z. (1995). Makedonskite dijalekti vo Egejska makedonija, Kniga 1. In: Sintaksa, Tom I. Skopje: MANU.

Zhang, L. (2019). A Study into the Prototypicality of Chinese Labile Verbs, Cognitive Semantics, 5, 1-31. DOI: 10.1163/23526416-00501001

\title{
ZEROWY WYKŁADNIK ALTERNACJI WALENCYJNYCH W JEZZYKU MACEDOŃSKIM
}

\begin{abstract}
ABSTRAKT: Artykuł omawia alternacje walencyjne, nie posiadające jawnego wykładnika w języku macedońskim. Wydaje się, że jest to ważna cecha typologiczna, która odróżnia macedoński od innych języków słowiańskich. W pracy przedstawiono ogólny opis tendencji labilności w odniesieniu do cech składniowych, semantycznych i dystrybucyjnych czasownika. Wykryto i przeanalizowano około 150 czasowników, wchodzących w labilność zachowującą przy alternacji patiensa i agensa. Czasowniki typu pierwszego przy zmianie perspektywy zachowują miejsce dla patiensa, ale $\mathrm{w}$ innej pozycji syntaktycznej (Toj sedna - Tie go sednaa. 'On siedział - Posadzili go'); typu drugiego zaś zachowują tematyczne miejsce dla agensa (Taa odi po poleto - Taa go odi poleto 'Idzie
\end{abstract}


przez pole - Idzie w pole'). Czasowniki zostały poklasyfikowane zgodnie z kryteriami składniowymi i semantycznymi po to, aby wskazać zdarzenia, które dopuszczają tego typu alternacje walencyjne oraz dominujące korelacje semantyczne, zachodzące między parami czasowników. 